\title{
Beliefs about the use of baby walkers
}

\author{
Crenças sobre o uso do andador infantil
}

Paula S. C. Chagas', Marisa C. Mancini², Marcella G. A. Tirado², Luiz Megale³ , Rosana F. Sampaio

\begin{abstract}
Objectives: To understand the opinion of the parents about the baby walker and compare the age of gait acquisition between infants that used a walker and those that did not. Methods: In this quali-quantitative study, an interview involving a semi-structured questionnaire was carried out with 26 parents, 14 of whose infants used the equipment (BWG) and 12 of whose infants did not (NBWG) prior to gait acquisition. After extensive content analysis, categories for interpreting the results emerged. For data triangulation, the age of gait acquisition was documented by weekly telephone contact. Student's t-test was used for comparison between groups with a significance level of $\alpha=0.05$. Results: The following categories were identified in the parents' reports: a) information about the baby walker; b) doubt/ decision to use it vs. certainty about not using it; c) beliefs about the use of a baby-walker; and d) benefits and harm from use. The age of independent gait acquisition did not differ between groups ( $p=0.837$ ): BWG initiated gait at 376.17 (SD=32.62) days and NBWG did so at 378.75 ( $S D=27.99)$ days. Conclusions: The beliefs and feelings that permeate the decision to use a baby walker illustrate the different rationales adopted by parents about the role of this equipment in the child's development of gait and autonomy. The use of a baby walker did not influence the age of gait acquisition. The results broaden the understanding of choices that influence child-rearing practices prior to gait acquisition.
\end{abstract}

Keywords: baby walkers; infants; beliefs.

\section{Resumo}

Objetivos: Conhecer a opinião dos pais sobre o uso do andador infantil e comparar a idade de aquisição da marcha independente entre os lactentes que usaram e os que não usaram o andador. Métodos: Neste estudo qualiquantitativo, realizou-se entrevista com questionário semiestruturado com 26 pais, 14 de lactentes que usaram (GUAI) e 12 dos que não usaram o equipamento (GNUAI) antes da aquisição da marcha. Empregou-se análise de conteúdo, a partir da qual, após extensa leitura, emergiram-se as categorias para interpretação dos resultados. Para triangulação dos dados, a idade de aquisição de marcha foi documentada por contato telefônico semanal e, para comparação entre grupos, usou-se o teste $t$ de Student, nível de significância $\alpha=0,05$. Resultados: Foram identificadas, nos relatos dos pais, as categorias: a) informações sobre o andador infantil; b) dúvida/decisão em usar versus certeza de não usar; c) crenças sobre o uso do andador infantil e d) benefícios e malefícios do uso. A idade de aquisição da marcha independente não foi diferente entre os grupos ( $p=0,837)$ : GUAl iniciou a marcha com 376,17 (DP=32,62) dias e GNUAI, com 378,75 $(\mathrm{DP}=27,99)$ dias. Conclusões: As crenças e sentimentos que permeiam a decisão de usar o andador ilustram racionalidades distintas entre os pais sobre o significado desse equipamento para o desenvolvimento da marcha e ganho de autonomia da criança. O uso do andador infantil não influenciou a idade de aquisição da marcha. Os resultados ampliam o entendimento das escolhas que podem influenciar as práticas maternas no período pré-aquisição da marcha.

Palavras-chave: andador infantil; lactentes; crenças.

Received: 23/07/2010 - Revised: 06/01/2011 - Accepted: 27/03/2011

${ }_{1}^{1}$ Physical Therapy Department of Elderly, Adult, Maternal and Infant, School of Physical Therapy, Universidade Federal de Juiz de Fora (UFJF), Juiz de Fora, MG, Brazil

${ }^{2}$ Department of Occupational Therapy, School of Physical Education, Physical Therapy and Occupational Therapy (EEFFTO), Universidade Federal de Minas Gerais (UFMG), Belo Horizonte, MG, Brazil ${ }^{3}$ Department of Pediatrics, School of Medicine, UFMG

${ }^{4}$ Physical Therapy Department, EEFFTO, UFMG

Correspondence to: Marisa Cotta Mancini, Programa de Pós-graduação em Ciências da Reabilitação, Escola de Educação Física, Fisioterapia e Terapia Ocupacional, Universidade Federal de Minas

Gerais, Avenida Antônio Carlos, 6627, CEP 31270-901, Belo Horizonte, MG, Brasil, e-mail: mcmancini@pib.com.br 


\section{Introduction $: \therefore$.}

Child development results from a child's interaction with the physical, social and attitudinal contexts in which he/she lives $^{1}$. Parents have ideas about how to treat their children and act according to the beliefs and social and cultural experiences they have acquired ${ }^{2}$. Belief can be defined as an act of faith of unconscious origin ${ }^{3}$. It is a form of consent given to the truths about which one has conviction and is motivated by voluntary choice, which lead to sustained ideas, opinions or explanations ${ }^{3}$. Beliefs are accepted by faith and, if confirmed by experience, become knowledge ${ }^{3}$. Beliefs are ideas about the nature of reality that shape our perceptions ${ }^{4}$. Several authors have sought to understand the beliefs and myths that guide parent-child interactions and relationships ${ }^{2,5-11}$.

Garcia, Pérez and Ortiz ${ }^{11}$ investigated the beliefs of African mothers concerning the language development of their children who experienced delays in verbal acquisition. The results revealed that mothers, predominantly of low socioeconomic level, neither stimulated the oral communication of their children nor perceived language delay since they believed that children do not speak or understand orders before three years of age ${ }^{11}$. A study of cultural influences on breastfeeding showed that this act is strongly influenced by beliefs and taboos that are passed from generation to generation ${ }^{8}$.

Parents' decision-making about the use of a baby walker with their children can be based on cultural beliefs, social myths and/or personal interests. In a survey carried out in the United States, $77 \%(\mathrm{n}=118)$ of parents decided to buy a baby walker and, of those, $78 \%$ found the equipment beneficial and believed it accelerated gait acquisition ${ }^{12}$. Few (22\%) reported that the baby walker use delayed gait acquisition or that it caused accidents ${ }^{12}$. Although the American Association of Pediatrics advise against the use of this device due to the high number of accidents (i.e., staircase falls, head traumas) and the possible delay of gait acquisition related to its use ${ }^{13}$, this survey showed a high percentage of parents who chose to use baby walkers.

It is known that parents' decisions are a key determinant in daily practices with the child ${ }^{14}$. Their choices and behaviors regarding their children seem to be more markedly influenced by the values and beliefs that underlie their understanding and action than by guidance from health professionals or scientific evidence $^{10}$. The reasons why parents in Brazil use or do not use this equipment, as well as their perceptions about its use and its effects on gait development are still unknown. For rehabilitation professionals, this study may clarify the reasons behind parental decisions to use or not use baby walkers with their children.

The objectives of this study were to learn the parents' opinion about both the reasons for their choice and the effects of the use of baby walkers, as well as to determine the age of gait acquisition in normally-developed infants who either used or did not use the equipment before the onset of independent walking.

\section{Methods::}

Twenty-six caregivers of normally developed infants from the city of Belo Horizonte, MG, Brazil, were purposely selected to participate. The baby walker group (BWG) included 14 caregivers and the group that did not use a baby walker (NBWG) included 12. The children's parents decided whether or not to use a baby walker prior to gait emergence. This study was approved by the Research Ethics Committee of the Universidade Federal de Minas Gerais (UFMG), Belo Horizonte, MG, Brazil (ETIC n. 609/07) and participating parents gave their written informed consent.

After selection, a motor evaluation was carried in each family's home using the Alberta Infant Motor Scale (AIMS) ${ }^{15}$ in order to control for possible delays in motor development. For BWG parents, forms were given for recording the amount of time that the baby walker was used daily and any comments about its use (i.e., activities, infant satisfaction, falls). Weekly contact with parents of both groups identified the age at which independent walking was achieved.

After the acquisition of gait, which was defined as the ability of the infant to take five steps without support ${ }^{15}$, parents of both groups were interviewed by a researcher who used a semi-structured questionnaire ${ }^{16}$ to obtain the following information: how they first learned about the baby walker and what they heard about it, at what point they decided to use or not use the baby walker, what reasons led them to this decision, and what information about the equipment was given by their pediatrician. BWG parents were asked about their perceptions regarding its use. The interviews were recorded on a portable digital voice recorder (Nakashi ${ }^{\circledR}$ ).

All interviews were conducted during the first month postgait acquisition, in a place of better convenience for parents, with an average duration of 5.30 minutes (2.70 minutes NBWG, and 7.95 minutes BWG). The information was transcribed; the parents received the interview to read and to make possible changes, until the final version was approved.

QRS International NVIVO $8^{\circledR}$ software was used to organize the reports, identify the initial categories, to find similarities and differences among them, to select passages and to organize final categories for further outcome interpretation ${ }^{17}$. The analysis and interpretation of the results were performed using content analysis ${ }^{18}$ based on the theoretical reference of myths and beliefs ${ }^{3}$. The names appearing in the interviews are 
fictitious; respondents were identified by their relationship to the infant (mother, father or grandmother) and by the child's inclusion number in the study.

The age at which independent walking was achieved was compared between groups using Student's $t$-test for independent groups. Statistical Package for Social Sciences $\left(\mathrm{SPSS}^{\circledR}\right.$, v. 15.0) was used for the inferential analysis, with a significance level of $\alpha=0.05$.

The triangulation method compared the effects perceived by the parents with the age of gait acquisition of infants from both groups. This technique served to extend the analysis process, comparing the quantitative results with the reports of qualitative interviews ${ }^{19}$.

\section{Results $: \therefore$}

Of the 14 caregivers in BWG, 12 were the mothers of the infant. One of the interviews was conducted jointly with the mother and the father of the child and in another the grandmother (59 years) was interviewed separately because the decision to use the baby walker during daily child care was made by her. In NBWG, 12 mothers were interviewed. Regarding the sociodemographic characteristics of the sample, 20 respondents were college graduates, 18 were between 31 and 40 years old, 18 were from the upper classes (A1 or A2 - 16) ${ }^{20}$ and 19 of the infants were the firstborn. Nine mothers were health professionals, five were lawyers, two were engineers, two were business administrators, one was a housewife, one was a hairdresser, one was a chemist, one was a receptionist, one was a teacher and one was a college student. The grandmother was a housewife and the interviewed father was a business administrator. Descriptive characteristics of the infants and the interviewed participants in each group are shown in Table 1.

The NVIVO $8^{\circledR}$ software helped identify units of meaning common to both groups, which were structured as a tree (Figure 1) and are shown and discussed below.

Table 1. Descriptive information of the infants and parents interviewed in this study, in each group of infants that used the baby walker (BWG) and infants that did not use the baby walker (NBWG).

\begin{tabular}{|c|c|c|c|}
\hline \multicolumn{2}{|l|}{ Groups } & NBWG & BWG \\
\hline \multicolumn{2}{|l|}{$\begin{array}{l}\text { Age of children at the moment } \\
\text { of the interview (days)* }\end{array}$} & $\begin{array}{l}378.75 \\
(27.99)\end{array}$ & $\begin{array}{l}376.16 \\
(32.62)\end{array}$ \\
\hline \multirow[t]{2}{*}{ Sex of the infants ${ }^{\star \star}$} & Female & 7 & 5 \\
\hline & Male & 5 & 7 \\
\hline \multirow[t]{5}{*}{ SES** } & A1 & 2 & 2 \\
\hline & A2 & 7 & 5 \\
\hline & B1 & 2 & 3 \\
\hline & B2 & 1 & 1 \\
\hline & C1 & 0 & 1 \\
\hline \multirow[t]{4}{*}{ Level of parental education** } & College Graduate & 11 & 9 \\
\hline & Partial College & 0 & 1 \\
\hline & High School Graduate & 1 & 3 \\
\hline & Partial Elementary School & 0 & 1 \\
\hline \multirow[t]{3}{*}{ Interviewed ${ }^{\star \star}$} & Mothers & 12 & 12 \\
\hline & Grandmother & & 1 \\
\hline & Father & & 1 \\
\hline
\end{tabular}

*The numbers indicate the mean value and inside parenthesis, standart deviation; these values also represent the mean age (in days) of gait acquisition in each group. ${ }^{* *}$ The numbers indicate the frequency of participants obtained in each classification. SES: Social economic status according to the Associação Brasileira de Empresas de Pesquisa (ABEP).

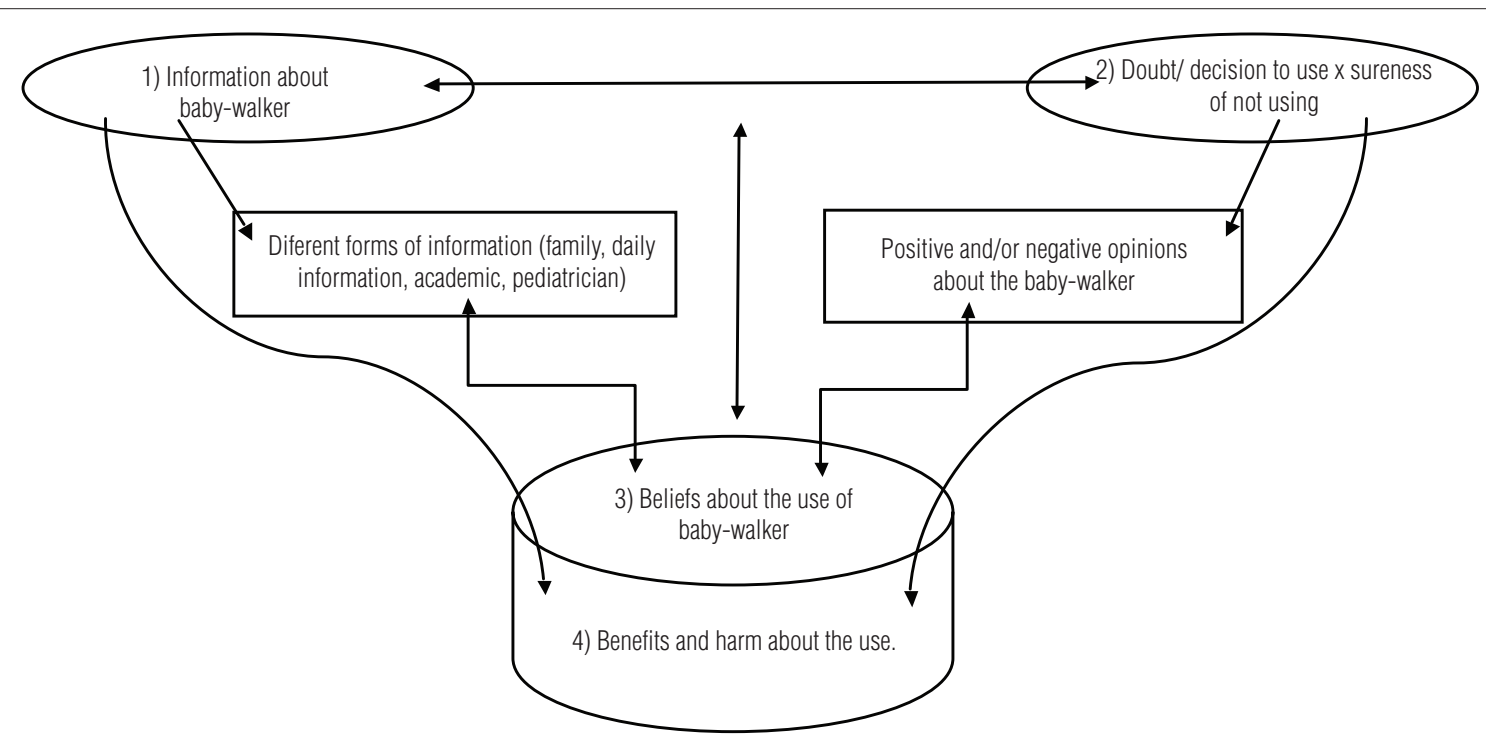

Figure 1. Final structure of the categories based on the content analysis of the interviews, contructed with the software NVIV08 QRS Internacional. In rounded format, the categories used for the interpretation of the results, and in retangular format, a resume of the information gathered in the reports that influenced the contruction of the categories. 


\section{Discussion $: \because$.}

\section{Information about the baby walker}

Sources of information about the use of baby walkers included family, daily life, academic/university activity and pediatricians. Mothers of both groups heard positive opinions about the baby walker:

And she says [the child's grandmother] that we walk even faster [...] with the help of the baby walker (NBWG07's mother); I heard that it was a way for the child to play and at the same time accelerated his walking skills by making his legs stronger (BWG10's mother); [...] my sister-in-law used a baby walker[...] and she gave me hers [...] I said: I'll use it to give my lap a rest (BWG07's mother).

Some of the BWG mothers heard inconclusive or contradictory information regarding the equipment:

I found it very interesting because it looked like some people loved it and others hated it. Some of my friends said "It's wonderful, he'll love it; use it and he will be very happy". But, on the other hand, other people said: "Don't use it. It's very dangerous, he'll fall. Don't use it". So I found it very strange that there was no middle ground: either people think it's great or they hate it (BWG02's mother).

NBWG mothers reported having received negative and unfavorable information about using the device:

A terrible accident happened to child who began to run with the baby walker and then suddenly tripped over something; and I've even heard of cases of head trauma [speaking slowly] from using the baby walker (NBWG05's mother); [... when I was in college they said that [the baby walker] was not to be recommended ... because it changes the child's gait pattern (NBWG06's mother); I heard bad things about it [...] that it was bad for motor coordination and for muscle strengthening (NBWG01's mother).

Pediatrician opinion seems to have indicated possible negative effects of the baby walker and, thus, influenced the parents of the NBWG not to use it with their children:

[...] he always says that the baby walker affects the child's gait ... (NBWG12's mother); [...] Adriana has already had two pediatricians: the first one told me that it was not recommended because the child was not yet ready to walk or balance himself and that its use would be a setback in the future when the child walked without it [...] this other pediatrician also told me the same thing, but she added that it would also delay her fine motor skills (NBWG1l's mother).

For BWG mothers, the decision to use the baby walker was made independently of pediatrician advice since many of them did ask the doctor's opinion and, even when receiving a negative response, chose to use it with their children anyway:
[...] Beware of accidents, because the rate of head injury is high, it drags things that fall on the child's head. On the staircase, too, accidents. [...] And she is against it (BWG07's mother).

The negative opinions about the baby walker were based on the high occurrence of accidents and the belief that this equipment affects the acquisition of and/or causes changes in the child's gait pattern. A study conducted by the American Association of Pediatrics about accidents in early childhood showed that the use of a baby walker is frequently associated with accidents and that parents should be very careful when choosing to buy and use such equipment ${ }^{13}$. Nevertheless, the following question could be asked about this evidence: what is the cause of injuries in this age group - the baby walker itself or the lack of parent supervision when using this equipment?

Although many pediatricians are against the use of baby walkers, such positioning does not seem to be based on evidence or to directly impact parents' decision making. A study performed in England in 2003 showed that pediatricians are aware of the risks that this object poses in early childhood, but $89 \%$ argue that there is not enough evidence in the literature for them to influence the parents' final decision ${ }^{21}$. In a sample of 222 pediatricians, $74 \%$ advise parents not to use a baby walker with their children, but only $34 \%$ believe that their advice actually influences the family's final decision. In the present study, the parents were aware of the risks that the baby walker could offer, but the reasons for deciding to use it were not based on risk.

\section{Doubt/decision to use it versus certainty of not using it}

The uncertainty of BWG parents about whether or not to use a baby walker with their children was clearly evident in their interviews. Frequently, the hesitation was based on negative opinions that they received before deciding to use it, such as in the following report:

No, I really wasn't sure. My house has no stairs, so I was not too worried about that; there was no area where he could have been hurt [...] I decided to use it to see [...] if he'd like it or not (BWG02's mother).

Other BWG mothers reported liking the equipment:

I always said I would use it, I never had anything against the baby walker. I always thought it was a way of entertaining the child a little, because he can't always crawl, sometimes his knee might hurt, then I put him in the baby walker. When I got pregnant I bought one, it was also the first gift his father gave him (BWG10's mother); [...] She always liked to be held. She did not crawl, she did not develop on the ground and I could not get up with her in my lap, so when she was 8-9 months [...] we decided to borrow a baby walker to try and she loved it [...] (BWG06’s mother). 
Some of the NBWG mothers were sure that they would not use one with their children. This certainty existed from the moment they became mothers:

So, since [laughs] I became a mother, I never thought about the possibility of using the baby walker [...] from what I see from it's use with other children, in my view, there is a change in gait pattern [...] for me, ... the baby walker is not an instrument that stimulates the child's motor development! (NBWG06's mother). So I decided, I did not stop to think about it. It was an unconscious thing. "Oh, let's buy a baby walker. It's cute!" Oh no! No baby walker (NBWG04's mother).

The reasoning behind the decisions of each group was determinant of the resulting maternal behavior and was related to beliefs about the effects baby walkers.

\section{Beliefs about the use of baby walker}

The reports of BWG mothers illustrate beliefs about the following effects of its use in child development: it allows locomotion when the child does not or cannot crawl (BWG01's, BWG06's mothers), gives freedom/independence to the child (BWG06's, BWG02's, BWG04's mothers), gives the child confidence to move by himself (BWG10's mother), facilitates gait (BWG08's grandmother), accelerates gait acquisition (BWG03's, BWG10's mother), strengthens the legs (BWG10's mother, BWG05's father), is a toy for the child (BWG10's mother) and helps the child develop (BWG12's, BWG11's mother). Some mothers also pointed out that the baby walker allowed them the freedom to perform other activities and rest, seeing that whenever the child is in the walker he is no longer in their lap (BWG07's, BWG09's mother): [...] I could do things and I knew he was there (BWG09's mother).

In the other hand, mostly NBWG mothers believe that the baby walker damages and/or delays acquisition of independent walking (NBWG06's, NBWG07's, NBWG12's mother); slows or changes the development of balance and motor coordination (NBWG05's, NBWG01's mother); leads the child to skip developmental steps (NBWG09's mother); affects leg strengthening (NBWG01's mother); causes accidents, falls and head trauma (NBWG02's, NBWG03's, NBWG05's mother). To this group of mothers, children who use the baby walker learn to run but not to walk (NBWG09's mother) and become lazy and insecure about walking (NBWG03's mother). In addition, mothers of both groups reported that health professionals discourage its use, arguing that it delays gait acquisition (BWG01's mother), changes gait pattern (NBWG06's, NBWG08's mother), causes equinus foot (BWG07's mother), bends the leg (NBWG11's, NBWG03's mother) and affects fine motor skills (NBWG11's mother).
Such beliefs interfered with the parent's decision to use a baby walker. A study performed in the United States ${ }^{22}$ specified that the main factor (79\% of the cases) that led mothers not to use it was the risk of accidents. In a study by DiLillo, Damashek and Peterson ${ }^{22}$, the reasons cited by mothers who chose to use it were very similar to those found in the present study, including: it is fun for the child, it facilitates child development, they believe that its helps the child to walk, they think that their home environment is safe for such equipment $^{22}$.

Although beliefs guide decision-making about baby walker use and parents believe that the baby walker either accelerates (BWG) or delays (NBWG) the ability to walk independently (which is also the oppinion of the American Association of Pediatrics ${ }^{13}$ ), no difference in age of gait acquisition between the groups ( $\mathrm{p}=0.837$ ) was found in the present study. Infants in the BWG achieved gait at 376.17 (SD=32.62) days and those in the NBWG at 378.75 (SD=27.99) days. The average time spent in the baby walker was $51.72 \mathrm{~min} /$ day (SD=29.13). Between 8 and 11 months of age was reported as the period that the infants spent the greatest amount of time in the equipment.

The quantitative results revealed that the age of gait acquisition was not influenced by the use of the baby walker, and that the infants in this study used the device less than one hour/day. This result corroborates evidence from two randomized clinical trials, which also reported no differences in age of gait acquisition in infants ${ }^{23,24}$. So far, the available scientific evidence shows that the use of a baby walker does not delay the age of gait acquisition ${ }^{25,26}$, although the American Association of Pediatrics does not recognize its benefits and recommends the prohibition of its use ${ }^{13}$.

\section{Benefits versus harm from its use}

Mothers who chose to use the baby walker realized benefits, contrary to the negative expectations engendered by their beliefs. It appears that the content of their beliefs was modified by their own experience using a baby walker with their children. This argument reinforces the dynamic characteristic of beliefs, since the acquisition of new information modifies the original beliefs, allowing the emergence of a new reality of reference ${ }^{27}$ :

[It] helped... not by creating strength in the leg, which was what everyone said, but... by giving more confidence to walk alone ... even in the baby walker, trying to stay balanced, to stand [...] but in the sense of encouraging walking, which, perhaps without the support, he would not have succeeded (BWG10's mother); [...] I have not noticed anything different in Paulo's leg or thigh [They said,] "it will be like a crankshaft, it will be different"... 
He's fine. I think he is more active, more independent... [...] He could go there and get something. And then, he got out of the baby walker and now he's walking, he is more active (BWG04's mother).

Although the mothers' expectations were focused on effects related to physical components and musculoskeletal characteristics of the lower limbs, the effects they observed included other aspects such as a sense of self-efficacy and a more independent and proactive attitude of the child in the home environment. In summary, mothers who felt that using a walker with their children was beneficial found several advantages. The first was that it stimulated development and independence: I thought it was cool. [...] I think she really liked it [laughs] [...] I go from one place to another, I can reach the things that I want. [...] I think it was fun for her. It was a way to help explore things (BWG06's mother). The second was that it afforded freedom for the mother: Great! [...] tranquility to get involved with other things [...] I wanted to work as well. It helped me a lot! (BWG03's mother). The third was infant satisfaction: [...] I thought it was great for him,... the sensation of his happiness, you know? Happiness when he was there playing [...] he was so happy that I thought "Oh, no supposed risk [laughs] could outweigh his happiness" (BWG02's mother).

The benefits perceived by Brazilian mothers are very similar to those reported in studies conducted in other countries $^{12,22-28}$. However, two did not like using the baby walker with their children. One of them thought it was risky in that it allowed access to dangerous places and objects. According to this mother, the child was displeased about being put in the baby walker while she performed domestic tasks. And it is really dangerous! And another thing, he really pulls things [...] but the baby walker multiplied [this problem] [...] it really snags things and they fall! The baby walker turns over! (BWG07's mother).

In another mother's evaluation, the child skipped stages of development, being made to walk when he was still too "soft" (BWG05's mother). The father, who also participated in this interview, argued that the baby walker could be positive for child development when used within certain limits and not as a rest for caregivers. The responses in this interview questioned relevant aspects about the routine of use and the proper time to begin its use.

This was the first qualiquantitative study with Brazilian mothers on beliefs about the use of the baby walker. One limitation is the composition of the study sample, which included families of middle and upper social classes who were college graduates, as well as several NBWG mothers $(n=6)$ who were health professionals.

The beliefs that influenced the decision to use the baby walker illustrate different the rationales of mothers about its effects on child development. The results broaden the understanding of choices that underlie maternal practices and may help rehabilitation professionals formulate guidelines for parents about the use of this equipment.

\section{Acknowledgments $: \because$.}

To the Conselho Nacional de Desenvolvimento Cientifico e Tecnológico (CNPq) and to the Fundação de Amparo à Pesquisa do Estado de Minas Gerais (FAPEMIG) for financial support (CDS - Programa Pesquisador Mineiro - $\mathrm{n}^{\circ}$. 00185-08), to the Coordenação de Aperfeiçoamento de Pessoal de Nivel Superior (CAPES) for the doctorate scholarship, and to the respondents for participating in this study.

\title{
References :
}

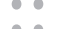

1. Darling N, Steinberg L. Parenting style as context: an integrative model. Psychological Bulletin. 1993;113(3):487-96.

2. Melchiori LE, Alves ZMMB. Crenças de educadoras de creche sobre temperamento e desenvolvimento de bebês. Psicol: Teor Pesqui. 2001;17(3):285-92.

3. Le Bon G. As opiniões e as crenças. São Paulo: Editora Ícone; 2002.

4. Strout MW, Thorn BE, Jensen MP, Boothby JL. The relation between pain beliefs, negative thoughts, and psychosocial functioning in chronic pain patients. Pain. 2000;84(2-3):347-52.

5. Rabuske MM, Oliveira DS, Arpini DM. A criança e o desenvolvimento infantil na perspectiva de mães usuárias do Serviço Público de Saúde. Estud Psicol (Campinas). 2005;22(3):321-31.

6. Lordelo ER, Fonseca AL, Araujo MLVB. Responsividade do ambiente de desenvolvimento: crenças e práticas como sistema cultural de criação dos filhos. Psicol Reflex Crít. 2000;13(1): 73-80.

7. Melchiori LE, Alves ZMMB, Souza DC, Bugliani MAP. Familia e creche: crenças a respeito de temperamento e desempenho de bebês. Psicol: Teor Pesqui. 2007;23(3):245-52.
8. Ichisato SMT, Shimo AKK. Aleitamento materno e as crenças alimentares. Rev Latinoam Enferm. 2001;9(5):70-6

9. Rapoport A, Piccinini CA. A escolha do cuidado alternativo para o bebê e a criança pequena Estud Psicol (Natal). 2004;9(3):497-503.

10. Lamy ZC, Gomes R, Carvalho M. A percepção de pais sobre a internação de seus filhos em unidade de terapia intensiva neonatal. J Pediatr (Rio J). 1997;73(5):293-8.

11. Garcia SB, Pérez AM, Ortiz AA. Mexican american mother's beliefs about disabilities. Rem Spec Educ. 2000;21(2):90-100.

12. Bar-on ME, Boyle RM, Endriss EK. Parental decisions to use infant walkers. Inj Prev. 1998;4(4):299-301

13. American Academy of Pediatrics; Committee on Injury and Poison Prevention. Injuries associated with infant walkers. Pediatrics. 2001;108(3):790-2.

14. Kolobe TH. Childrearing practices and developmental expectations for Mexican-American mothers and the developmental status of their infants. Phys Ther. 2004;84(5):439-53. 
15. Piper MC, Darrah J. Motor assessment of the developing infant. Philadelphia: W.B. Saunders Company; 1994.

16. Fontanella BJB, Campos CJG, Turato ER. Data collection in clinical-qualitative research: use of non-directed interviews with open-ended questions by health professionals. Rev Latinoam Enferm. 2006;14(5):812-20.

17. NVivo qualitative data analysis software [computer program]. Version 8.0 QSR International Pty Ltd; 2008.

18. Bardin L. Análise de conteúdo. Lisboa: Edições 70; 1979.

19. Pope C, Mays N. Pesquisa qualitativa na atenção a saúde. $2^{\text {a }}$ ed. Porto Alegre: Artmed; 2006

20. Associação Brasileira de Empresas de Pesquisa. Critério de classificação econômica Brasil 2008. www abep org 2008 [cited 2008 May 26];

21. Rhodes K, Kendrick D, Collier J. Baby walkers: paediatricians' knowledge, attitudes, and health promotion. Arch Dis Child. 2003:88(12):1084-5.
22. DiLillo D, Damashek A, Peterson L. Maternal use of baby walkers with young children: recent trends and possible alternatives. Inj Prev. 2001;7(3):223-7.

23. Kaufmann IB, Ridenour MV. Influence of an infant walker on onset and quality of walking pattern of locomotion: an electromyographic investigation. Percept Mot Skills. 1977;45(3 Pt 2):1323-9.

24. Ridenour MV. Infant walkers: developmental tool or inherent danger. Percept Mot Skills 1982;55(3 Pt 2):1201-2.

25. Chagas PSC, Cunha RSM, Mancini MC, Magalhaes LC. There is no evidence to support or refute the effect of baby walkers on motor development in typically developing children. www otcats com 2007 [cited 2007 0ct 1];1-17.

26. Burrows $\mathrm{P}$, Griffiths $\mathrm{P}$. Do baby walkers delay onset of walking in young children? $\mathrm{Br} \mathrm{J}$ Community Nurs. 2002;7(11):581-6.

27. Pollock JL, Gillies AS. Beliefs revision and epistemology. Synthese. 2000;122(1-2):69-92.

28. Dogan DG, Bilici M, Yilmaz AE, Catal F, Keles N. Baby walkers: a perspective from Turkey. Acta Paediatr. 2009;98(10):1656-60. 